\title{
Effect of Different Levels of Nitrogen on Yield of Colocasia (Colocasia esculenta) at District Malakand Dargai
}

\section{Rafiq Ahmad1, Dost Muhammad1, Maria Mussarat'1, Shah Fahad'2, Shahid Ullah ${ }^{3}$, Taimur Ahmad4, Sara Wahab ${ }^{5}$}

${ }^{1}$ Department of Soil and Environmental Sciences, The University of Agriculture, Peshawar, Pakistan

${ }^{2}$ University of Swabi, Swabi, Pakistan

${ }^{3}$ Department of Agronomy, The University of Agriculture, Peshawar, Pakistan

${ }^{4}$ Department of Horticulture, AMK Campus Mardan, The University of Agriculture Peshawar, Peshawar, Pakistan

${ }^{5}$ Department of Zoology, Abdul Wali Khan University Mardan, Mardan, Pakistan

Email: rafiqsoil5454@yahoo.com

How to cite this paper: Ahmad, R., Muhammad, D., Mussarat, M., Fahad, S., Ullah, S., Ahmad, T. and Wahab, S. (2018) Effect of Different Levels of Nitrogen on Yield of Colocasia (Colocasia esculenta) at District Malakand Dargai. Open Journal of Soil Science, 8, 87-98.

https://doi.org/10.4236/ojss.2018.82007

Received: December 7, 2017

Accepted: February 24, 2018

Published: February 27, 2018

Copyright (c) 2018 by authors and Scientific Research Publishing Inc. This work is licensed under the Creative Commons Attribution International License (CC BY 4.0).

http://creativecommons.org/licenses/by/4.0/

\begin{abstract}
A field experiment was conducted to evaluate the response of colocasia ( $\mathrm{Co}$ locasia esculenta) to different levels of $0,60,90,120$ and $150 \mathrm{~kg} \mathrm{~N} \mathrm{ha}^{-1}$ under farmer's field condition at Garhi Usmani Khel, District Malakand Dargai during 2013. The experiment was laid out in Randomized Complete Block design with three replications and treatment plot size of $2.74 \times 2.43 \mathrm{~m}^{2}$. All levels of $\mathrm{N}$ in the form of urea along with uniform basal doze of $90 \mathrm{~kg} \mathrm{P}_{2} \mathrm{O}_{5} \mathrm{ha}^{-1}$ as Triple Super Phosphate (TSPPP) were applied to soil at time of seed bed followed by thorough mixing. Seeds of colocasia c.v. local variety were sown in these plots with row spacing of $30 \mathrm{~cm}$ and plant to plant distance of $12 \mathrm{~cm}$ in February, 2013. The results showed that application of $\mathrm{N}$ produced significantly higher colocasia tuber yield, number of tubers plant ${ }^{-1}$, 1000-tubers weight and size of tubers (mean length and diameter) over control but the differences among levels of $\mathrm{N}$ were nonsignificant. However, some parameters like tuber yield was maximum at $60 \mathrm{~kg} \mathrm{~N} \mathrm{ha}^{-1}$ and tuber size especially the length of colocasia tuber was maximum at $150 \mathrm{~kg} \mathrm{~N} \mathrm{ha}^{-1}$ suggesting that the response of each parameter was different to $\mathrm{N}$ levels. Based on maximum relative yield (100\%) and increase over control (46.1\%) still at lower $\mathrm{N}$ levels of $60 \mathrm{~kg} \mathrm{~N} \mathrm{ha}^{-1}$, this level seems to be appropriate level for colocasia under the prevailing soil and climatic conditions.
\end{abstract}

\section{Keywords}

Colocasia esculenta, Nitrogen, Tuber Yield, Agronomic Character, Pakistan 


\section{Introduction}

Colocasia (Colocasia esculenta) having about 25 species is a group of flowering plants widely used for food and landscaping purposes [1]. Leaves of these plants are shaped like shields or arrow head each growing on a single stem and ranging from 25 to $150 \mathrm{~cm}$ across. The large floppy leaves of colocasia gave the plant a common name, elephant ear. In the garden they are prized as ornamental plants growing as a focal point in the back of a landscaping plan [2]. Several varieties produce different plant sizes, leaf shape, and different colors ranging from bright green through reddish-tinged and black-outlined foliage. Colocasia grows best in tropical areas with plentiful water. When the plants dry out, the leaves fold, droop and will develop dry brown spots or edges after a drought. The plant can be cultivated by planting the tubers or rhizomes just below the surface or mature plants can be set into pre-watered holes.

As a food plant, colocasia is used throughout Africa, the Caribbean and South America, and as well as in Asia and Pakistan. Nowadays, it is considered the fifth most consumed root vegetable worldwide [3]. The edible varieties are called taro, cocoyam, dasheen or eddoe. Taro is one of the few major staple foods where both the leaf and underground parts are important in the human diet [4]. The tubers of the plant are white-fleshed with a dark-colored bark that is peeled before eating and the flavor is somewhat similar to a potato. The corms supply easily digestible starch and are known to contain substantial amounts of protein, vitamin $\mathrm{C}$, thiamine, riboflavin, niacin and significant amounts of dietary fiber [5]. The leaves have a taste similar to spinach or collards. The leaves are high in minerals and vitamins $\mathrm{A}, \mathrm{C}, \mathrm{K}, \mathrm{Ca}, \mathrm{P}, \mathrm{Fe}$, thiamine and niacin [6]. The Caribbean dish callaloo, a stew with variable ingredients always contains the chopped leaves of the colocasia plant and sometimes also includes the chopped tubers. Some South American cultures dry the tubers and pound them into flour to be used in baking and as a thickening agent. Harvesting takes place when the plants are 7 - 8 months old or when only three functional leaves remain on the plant. Yields are estimated to range from $4-7$ tons of marketable corms (tubers) per hectare [7].

Like other agricultural and ornamental plants, balanced nutritional supply play the key role in production of colocasia. Among these nutrients, the nitrogen which is required in higher amounts by plants and is often deficient in most areas is relative more responsive. The farmers and growers all over the world primarily focus on nitrogen application before any other nutrient. Though nitrogen is an abundant element on and around Earth-approximately 78 percent of the earth's atmosphere is nitrogen gas [8] but it is not available to plant in this form. It is frequently deficient in soils including the tropical soils as well [9]. Nitrogen has numerous functions in the plant. Many plant enzymes are proteinaceous and hence nitrogen play a key role in many metabolic reactions of plant and adequate $\mathrm{N}$ promotes vigorous vegetative growth and impart deep green color. In cereals crops it increase the plumpness of a grains. Nitrogen is also the 
part of chlorophyll molecule so a deficiency of nitrogen will result in a chlorotic condition of the plant which decreases the quality of its fruits. Plant root absorb $\mathrm{N}$ in the form of a $\mathrm{NO}_{3}^{-}$or $\mathrm{NH}_{4}^{+}$ions. Urea $\left(\mathrm{NH}_{2} \mathrm{CONH}_{2}\right)$ can also be absorbed by plant leaves when applied in solution form as a foliar application. In this form $\mathrm{N}$ is directly and rapidly absorbed through the leaf epidermis. In colocasia as well, the application of $\mathrm{N}$ significantly improve its yield and yield components [10]. However, the optimum level of $\mathrm{N}$ has not been extensively studied and probably not at all in local conditions of the province. This study was initiated to evaluate the optimum level of $\mathrm{N}$ required for higher yield of colocasia under the local conditions of Malakand Dargai. Keeping in view the importance of nitrogen for enhancing the yield of colocasia, the present study was therefore, designed to evaluate the effect of different levels of $\mathrm{N}$ on its yield and to select the best level of $\mathrm{N}$ for higher yield and yield components of colocasia under agro climatic condition of village Garhi Usmani khel Dargai Malakand.

\section{Materials and Methods}

\subsection{Field Experimentation}

An experiment was conducted to determine the effect of different levels of nitrogen on the yield and yield components of colocasia at District Malakand village Garhi Usmani Khel during 2013. The study was consisted of five level of nitrogen $0,60,90,120$ and $150 \mathrm{~kg} \cdot \mathrm{ha}^{-1}$. The experiment was conducted in randomized complete block design with three replications having plot size $2.74 \mathrm{~m} \times$ $2.43 \mathrm{~m}$. Local colocasia variety was sown on a well prepared clay soil. The spacing between plant to plant $12 \mathrm{~cm}$ and row to row was $30 \mathrm{~cm}$. In each row $12 \mathrm{co}-$ locasia tubers were planted. The entire quantity of nitrogen in the form of urea was applied to the respective plots at seed bed preparation. The crop was sown in February and then harvested in October. Data on number of colocasia $\operatorname{plot}^{-1}$, 1000-tubers weight, length, diameter and total yield of colocasia was recorded. Manual weeding was performed three times in the cropping season. After 3 months of the emergence of colocasia ridges were performed for better production of colocasia tubers.

During month of May fungal disease called blight of colocasia appeared and was controlled by a fungicide Metalixal + Mancozeb 72\% wp@ 3 gm per liter three times at the interval of 10 days the whole month. In month of June crop was again attacked by insects (worms) and Chlorpyrifos $40 \mathrm{ec}+$ Acetamiprid $20 \% \mathrm{sp}$ insecticide was used at $3 \mathrm{gm}$ per 10 liter. A high rainfall in the month of august caused a severe brownish spots on leaves that was a fungal attack. Metalixal + Mancozeb 72\% wp@ 3 gm per liter and Acetamiprid 20\% sp of 3 gm per 10 liter was used 3 time at 10 days interval the whole month. The colocasia was harvested at the month of October. All other agronomic practices such as irrigation and plant protection measures etc were kept normal and uniform for all the experimental units. Data on tuber yield $\left(\mathrm{kg} \cdot \mathrm{ha}^{-1}\right)$, number of tuber per plant, weight of tubers and size of tuber were recorded. 


\subsection{Statistical Analysis}

The data was analyzed, thus Analysis of variance (ANOVA) procedure for randomized complete design by a statistic 8.1 software. The variations between the treatments were compared by LSD test of significance [11].

\section{Laboratory Analysis}

Four composite soil samples were collected and passes through $2 \mathrm{~mm}$ sieve to separate roots and plant stubbles. Soil samples were analyzed for physical and chemical properties of soil such as soil texture, $\mathrm{P}^{\mathrm{H}}, \mathrm{EC}, \mathrm{OM}, \mathrm{AB}-\mathrm{DTPA}$ extractable Phosphorus (P) and total $\mathrm{N}$ as shown in Table 1.

\subsection{Soil Texture}

The Hydrometer was used to investigate texture of soil as presented by [12]. Take $50 \mathrm{~g}$ soil and then added $10 \mathrm{ml}$ of $\mathrm{Na}_{2} \mathrm{CO}_{3}$ and water into a dispersion cup. Shake for 5 minutes through dispersing machine to break up all the aggregates. Reading was noted in hydrometer after 40 second and after 2 hours along with the temperature. First reading mean after 40 second represent silt and clay while 2 hour reading shows clay in the suspension.

\subsection{Soil PH}

Ten grams of soil was added to $50 \mathrm{ml}$ of distilled water and then shake for 20 30 minutes to make a 1:5 suspension. The $\mathrm{pH}$ was determined in the suspension using $\mathrm{pH}$ meter (Inolab WTW Series $\mathrm{pH}$ 720) after calibrating the instrument with standard buffers of 4.0 and 10.0.

\subsection{Soil EC}

The electrical conductivity was calculated in soil suspensions of 1:5 by using EC meter after calibration with KCL standard solution as presented by [13].

\subsection{Organic Matter}

Organic matter was calculated by [14]. $1 \mathrm{gm}$ of dried soil was taken in a conical

Table 1. Experimental field pre-harvest soil physico-chemical properties.

\begin{tabular}{ccc}
\hline Properties & Units & Values \\
\hline Clay & $\%$ & 13.8 \\
Silt & $"$ & 30 \\
Sand & $"$ & 56.2 \\
Textural Class & - & Sandy loam \\
$\mathrm{pH}_{(1: 5)}$ & - & 7.15 \\
EC $_{(1: 5)}$ & $\mathrm{dSm}^{-1}$ & 0.13 \\
OM (\%) & $\%$ & 0.99 \\
Extractable (AB-DTPA) P & ${\mathrm{mg} \cdot \mathrm{kg}^{-1}}^{-1}$ & 2.02 \\
Total N & $\%$ & 0.113 \\
\hline
\end{tabular}


flask along with $10 \mathrm{ml}$ of $0.5 \mathrm{~N} \mathrm{~K}_{2} \mathrm{Cr}_{2} \mathrm{O}_{7}$ and $20 \mathrm{ml}$ of conc. $\mathrm{H}_{2} \mathrm{SO}_{4}$. It was then allowed to stand for $30 \mathrm{~min}$ to complete the reaction. After sometime add $200 \mathrm{ml}$ of distilled water and the suspension was filtered. Then 2 - 3 drops of Ortho phenolphthalein indicator was added to the filtrate. It was then titrated against $0.5 \mathrm{~N} \mathrm{Fe}_{2} \mathrm{SO}_{4} \cdot 7 \mathrm{H}_{2} \mathrm{O}$ until the color changed to dark brown, representing the end point. The percent organic matter was calculated using the following formula.

$$
\% \mathrm{OM}=\frac{\left[\left(\mathrm{mL} \text { of } \mathrm{K}_{2} \mathrm{Cr}_{2} \mathrm{O}_{7} \times \mathrm{N}\right)-\left(\mathrm{mL} \text { of } \mathrm{FeSO}_{4} \cdot 7 \mathrm{H}_{2} \mathrm{O} \times \mathrm{N}\right)\right]}{\text { Weight of soil }} \times 0.69
$$

\subsection{AB-DTPA Extractable P}

$\mathrm{P}$ concentration in soil sample was determined by extracting soil solution with AB-DTPA as presented by [15]. $10 \mathrm{~g}$ of soil and $20 \mathrm{ml}$ of AB-DTPA solution was added to a conical flask and placed on shaking machine for 15 minutes. Then the samples were filtered with Watman No. 42. One $\mathrm{ml}$ sample along with $5 \mathrm{ml}$ of ascorbic acid was taken and made the volume up to $25 \mathrm{ml}$. Then with the help of spectrophotometer (Lambda-35), $\mathrm{P}$ was determined at $880 \mathrm{~nm}$ after proper color development.

\subsection{Determination of Total $\mathrm{N}$ in Soil}

Kjeldhal method of [16] is used to evaluate total $\mathrm{N}$ in soil and plant samples. Finely 0.2 g ground sample of dry materials were digested with $3 \mathrm{ml}$ of concentrated $\mathrm{H}_{2} \mathrm{SO}_{4}$ in the presence of $1.1 \mathrm{~g}$ digestion mixture containing $\mathrm{CuSO}_{4}, \mathrm{~K}_{2} \mathrm{SO}_{4}$ and Se on a heating mantle for 1 hour. The digest was transferred into the distillation flask and distilled in the presence of $10 \mathrm{ml}$ of $10 \mathrm{M} \mathrm{NaOH}$ solution. The distillate was then taken in $5 \mathrm{ml}$ boric acid mixed indicator solution and then titrated against $0.01 \mathrm{M} \mathrm{HCl}$. Calculation for total nitrogen in soil are as Follow:

Total N $(\%)=($ Sample-Blank $) \times 0.005 \times 0.014 \times 100 \times 100 /$ Wt. of soil $\times 20 \mathrm{nt}$

\section{Results and Discussion}

\subsection{Tuber Yield Data}

Data regarding yield of colocasia are given in Table 2. Analysis of the data showed that nitrogen levels significantly $(P \leq 0.05)$ affected yield of colocasia. The highest yield of colocasia $14.15 \mathrm{t} \cdot \mathrm{ha}^{-1}$ was recorded in the plot treated with $60 \mathrm{~kg} \mathrm{~N} \mathrm{ha}{ }^{-1}$, followed by $90 \mathrm{~kg} \mathrm{~N} \mathrm{ha}{ }^{-1}$ with a yield of $13.59 \mathrm{t} \cdot \mathrm{ha}^{-1}$ of colocasia. The lowest yield with value of $9.63 \mathrm{t} \cdot \mathrm{ha}^{-1}$ was observed in control. Calculating the increase in yield, the application of $60 \mathrm{~kg} \mathrm{~N} \mathrm{ha}^{-1}$ increased the yield by $46.90 \%$ over the control (Table 2, Figure 1). However further application of $\mathrm{N}$ did not further increase this trend, rather it showed the decreasing trend. Both the increase over control and relative yield (Figure 1) showed the highest values at $60 \mathrm{~kg} \mathrm{~N} \mathrm{ha}^{-1}$ revealed that it could be the suitable and more economical level of $\mathrm{N}$ for colocasia under the prevailing soil and climatic conditions for the given variety. However, this level of $60 \mathrm{~kg} \mathrm{~N} \mathrm{ha}^{-1}$ seems much lower than the expected 
Table 2. The yield of colocasia as influenced by different levels of nitrogen.

\begin{tabular}{ccccc}
\hline Treatments & N levels & $\begin{array}{c}\text { Yield } \\
\left(\mathbf{t} \cdot \mathrm{ha}^{-1}\right)\end{array}$ & $\begin{array}{c}\text { Increase over } \\
\text { control } \\
(\%)\end{array}$ & $\begin{array}{c}\text { Relative yield } \\
\text { (\%) }\end{array}$ \\
\hline T1 & 0 & $9.63 \mathrm{~b}$ & - & 68.05 \\
T2 & 60 & $14.15 \mathrm{a}$ & 46.9 & 100.00 \\
T3 & 90 & $13.59 \mathrm{a}$ & 41.1 & 96.04 \\
T4 & 120 & $13.07 \mathrm{a}$ & 35.7 & 92.35 \\
T5 & 150 & $13.03 \mathrm{a}$ & 35.3 & 92.11 \\
\hline
\end{tabular}

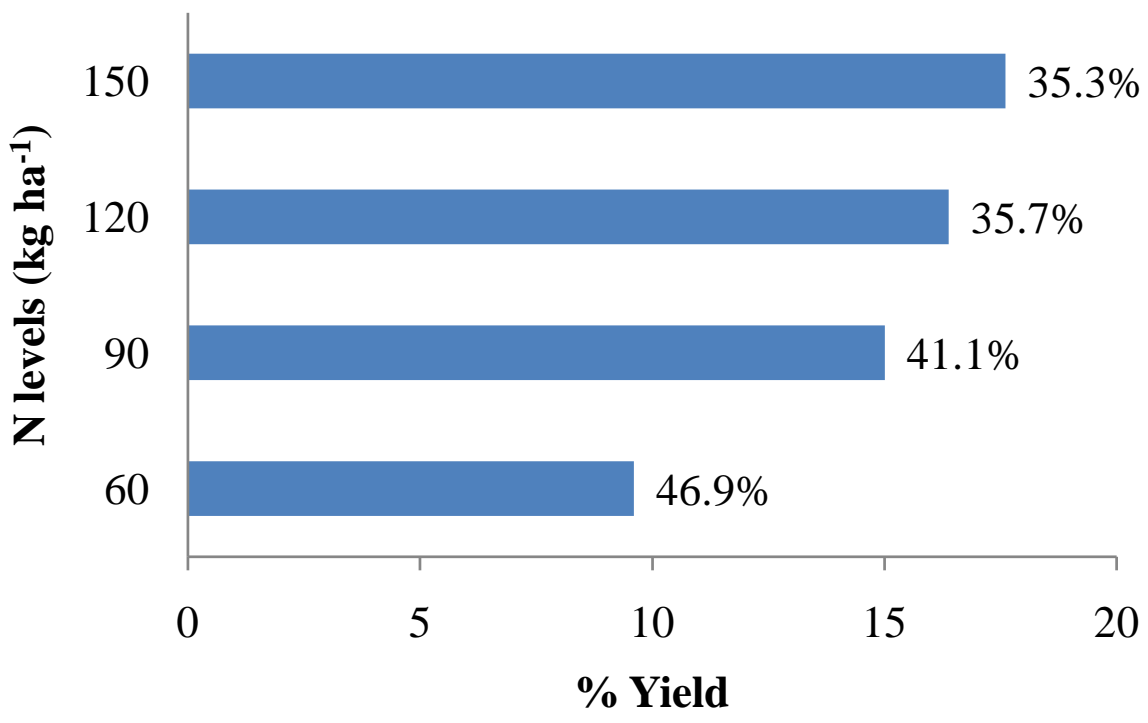

Figure 1. The yield of colocasia as influenced by different levels of nitrogen.

and reported values of [17] who used and recommended much higher value of $\mathrm{N}$ for economical yield of colocasia and sweet potato. Optimum levels of nitrogen fertilization for tuber yield in colocasia were found to be $79.62 \mathrm{~kg} \mathrm{~N}$ [18]. The result is in contrast with [19] who reported that maximum yield attributes and yield were found with $120 \mathrm{~kg} \mathrm{~N} \mathrm{ha}^{-1}$. Similarly, [20] reported that the highest stolon yield $\left(24.5 \mathrm{t} \cdot \mathrm{ha}^{-1}\right)$ was recorded with $125 \mathrm{~kg} \mathrm{~N} \mathrm{ha}^{-1}$ and $125 \mathrm{~kg} \mathrm{~K} \mathrm{ha}^{-1}$, which is in agreement with the findings of our study. [21] also observed the highest corm yield with $\mathrm{N}_{120} \mathrm{~K}_{120} \mathrm{~kg} \cdot \mathrm{ha}^{-1}$. No doubt the $\mathrm{N}$ requirements of the crop varies from soil to soil, crop to crop and variety and also the lower $\mathrm{N}$ requirement in our condition could be associated to lower yield potential of the crop variety. The local variety (lower yielding) was used in the said study as no higher yielding variety was available at time of sowing in the market.

\subsection{Tuber Weight}

Thousand colocasia weight $(\mathrm{kg})$ showed significant variation $(P \leq 0.05)$ with $\mathrm{N}$ applied. The maximum 1000 -colocasia weight of $31.18 \mathrm{~kg}$ was recorded in the plot receiving $90 \mathrm{~kg} \mathrm{~N} \mathrm{ha}^{-1}$, followed by $120 \mathrm{~kg} \mathrm{~N} \mathrm{ha}^{-1}$ with a weight of $27.41 \mathrm{~kg}$. 
The minimum weight of $22.92 \mathrm{~kg}$ was observed in control. Calculating the increase in yield, the application of $90 \mathrm{~kg} \mathrm{~N} \mathrm{ha}^{-1}$ increased the 1000 colocasia weight by $36 \%$ over control. (Table 3, Figure 2). Stolon length was increased with the application of more nitrogen [22] which in turn increases the 1000 stolon mass. Meanwhile, [23] reported the maximum number of leaves plant ${ }^{-1}$ with $80 \mathrm{~kg} \mathrm{~N} \mathrm{ha}^{-1}$ and $120 \mathrm{~kg} \mathrm{~K} \mathrm{ha}^{-1}$ which is the reason for the increase in the 1000 stolon weight. However further application of $\mathrm{N}$ did not further increase this trend, rather it showed the decreasing trend. Both the increase over control and relative yield (Figure 2) showed the highest values at $90 \mathrm{~kg} \mathrm{~N} \mathrm{ha}^{-1}$ revealed that it could be the suitable and more economical level of $\mathrm{N}$ for colocasia under the prevailing soil and climatic conditions for the given variety.

\subsection{Number of Colocasia Plant ${ }^{-1}$}

The data showed that number of colocasia tubers plant ${ }^{-1}$ was significantly $(P \leq$ 0.05 ) affected by different levels of nitrogen (Table 4). The maximum number 16.63 was observed in treatments receiving $90 \mathrm{~kg} \mathrm{~N} \mathrm{ha}^{-1}$ followed by $60 \mathrm{~kg} \mathrm{~N}^{-1}$

Table 3. The 1000 number of colocasia as influenced by different levels of nitrogen.

\begin{tabular}{ccccc}
\hline Treatments & N levels & $\begin{array}{c}1000 \text { tuber } \\
\text { weight } \\
(\mathbf{k g})\end{array}$ & $\begin{array}{c}\text { Increase over control } \\
(\%)\end{array}$ & $\begin{array}{c}\text { Relative weight } \\
\text { (\%) }\end{array}$ \\
\hline T1 & 0 & $22.92 \mathrm{c}$ & - & 73.52 \\
T2 & 60 & $25.56 \mathrm{~b} \mathrm{c}$ & 11.5 & 81.97 \\
T3 & 90 & $31.18 \mathrm{a}$ & 36.0 & 100.00 \\
T4 & 120 & $27.41 \mathrm{~b}$ & 19.6 & 87.92 \\
T5 & 150 & $26.61 \mathrm{c}$ & 16.1 & 85.35 \\
\hline
\end{tabular}

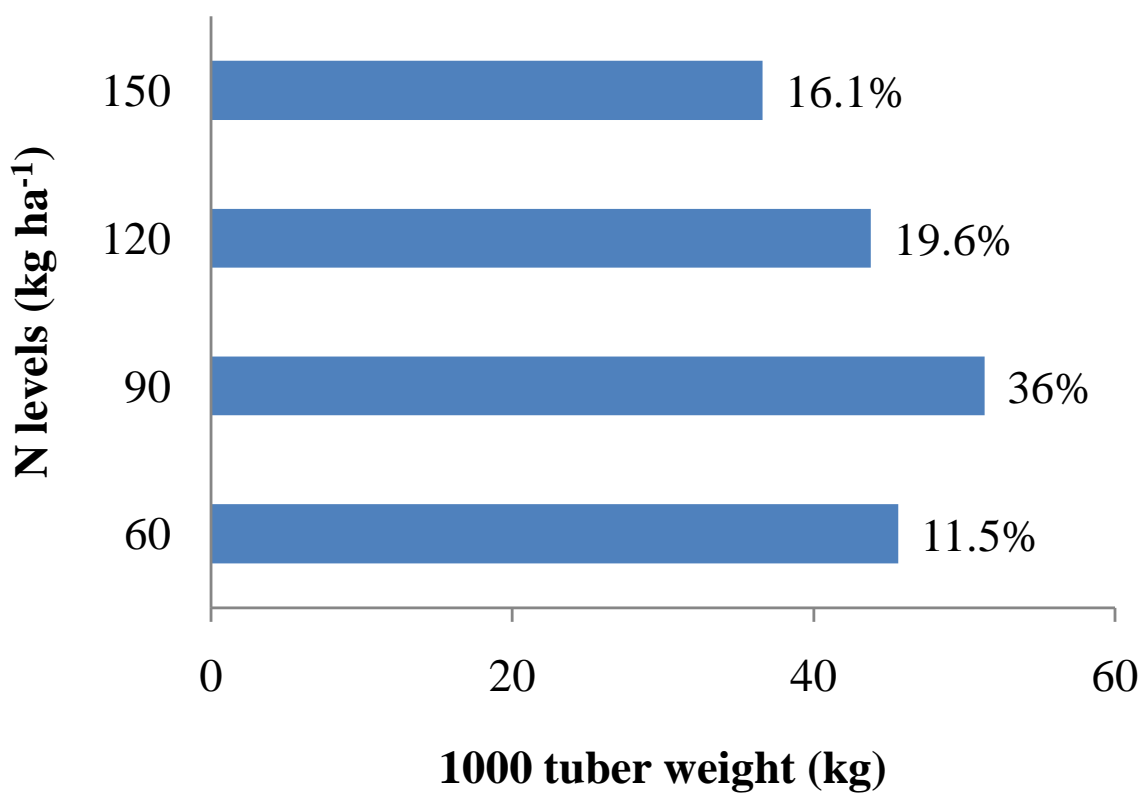

Figure 2. The 1000 number of colocasia as influenced by different levels of nitrogen. 
with a number of 16.0 colocasia plant ${ }^{-1}$. The minimum number of 10.99 colocasia tuber plant ${ }^{-1}$ was recorded in control. Calculating the increase in number of colocasia plant ${ }^{-1}$, the application of $90 \mathrm{~kg} \mathrm{~N} \mathrm{ha}^{-1}$ increased the number of colocasia plant ${ }^{-1}$ by $51.33 \%$ over the control (Table 4, Figure 3 ). Increase in the colocasia per plant is due to $\mathrm{N}$ increased which is associated with vegetative growth of plants [24]. It is also linked with vigorous vegetative growth, photosynthesis, and dark green color 11 pigmentations [25]. Availability of usable $\mathrm{N}$ in most agricultural conditions is a major limiting factor of plant growth and in most tropical soils yields of taro may be improved when inorganic $\mathrm{N}$ fertilizers are used. Studies conducted by [26] revealed that taro requires relatively high $\mathrm{N}$ especially in its early stages of growth. However further application of $\mathrm{N}$ did not increase this trend, rather it showed the decreasing trend. Both the \% increase over control and relative number of colocasia tuber plant $^{-1}$ (Figure 3) were maximum at $90 \mathrm{~kg} \mathrm{~N} \mathrm{ha}^{-1}$ revealed that it could be the suitable and more economical level of $\mathrm{N}$ for colocasia under the prevailing soil and climatic conditions for the given variety.

Table 4. The number of colocasia as influenced by different levels of nitrogen.

\begin{tabular}{ccccc}
\hline Treatments & N levels & $\begin{array}{c}\text { Number } \\
\text { No. plant }\end{array}$ & $\begin{array}{c}\text { Increase over control } \\
\text { (\%) }\end{array}$ & $\begin{array}{c}\text { Relative number } \\
\text { (\%) }\end{array}$ \\
\hline T1 & 0 & $10.99 \mathrm{~b}$ & - & 66.08 \\
T2 & 60 & $16.00 \mathrm{a}$ & 45.602 & 96.21 \\
T3 & 90 & $16.63 \mathrm{a}$ & 51.335 & 100.00 \\
T4 & 120 & $15.80 \mathrm{a}$ & 43.782 & 95.01 \\
T5 & 150 & $15.01 \mathrm{a}$ & 36.603 & 90.27 \\
\hline
\end{tabular}

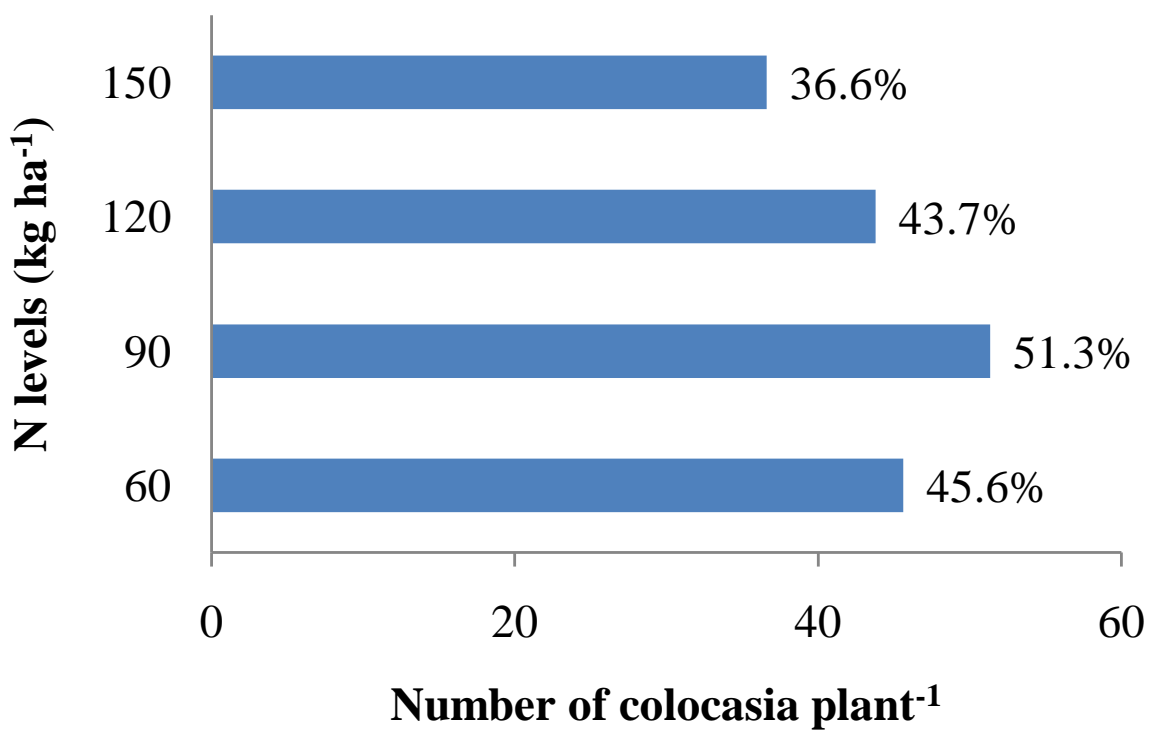

Figure 3. The number of colocasia as influenced by different levels of nitrogen. 


\subsection{Average Size of Colocasia}

Both maximum length and maximum diameter of the colocasia increased with increase in $\mathrm{N}$ levels (Table 5). The highest length of $5.84 \mathrm{~cm}$ was obtained in plots treated with $150 \mathrm{~kg} \mathrm{~N} \mathrm{ha}^{-1}$, followed by $120 \mathrm{~kg} \mathrm{~N} \mathrm{ha}^{-1}$ with a length of 5.78 $\mathrm{cm}$. The lowest length noted was $4.97 \mathrm{~cm}$ in a control. Calculating the increase in length, the application of $150 \mathrm{~kg} \mathrm{~N} \mathrm{ha}^{-1}$ increased the length by $17.62 \%$ over the $120 \mathrm{~kg} \mathrm{~N} \mathrm{ha}^{-1}$ (Table 5, Figure 4). Unlike other parameter, the length of tubers of colocasia increased with increase up to the higher level of $\mathrm{N}$ application as concluded by [20], he concluded that maximum stolon length was recorded with application of $\mathrm{N}$ at the rate of $125 \mathrm{~kg} \cdot \mathrm{ha}^{-1}$ (Figure 4). Increase in the stolon length might be due to increase in the photosynthesis as [27] observed the maximum number of leaves plant ${ }^{-1}$ of Colocasia esculenta, with $100 \mathrm{~kg} \mathrm{~N} \mathrm{ha}^{-1}$. While, [23] reported the maximum number of leaves plant ${ }^{-1}$ with $80 \mathrm{~kg} \mathrm{~N} \mathrm{ha}^{-1}$.

Similarly, the maximum mean diameter significantly $(P \leq 0.05)$ affected by different levels of nitrogen and the maximum mean diameter of $3.14 \mathrm{~cm}$ was recorded in plots treated with $90 \mathrm{~kg} \mathrm{~N} \mathrm{ha}^{-1}$, followed by $60 \mathrm{~kg} \mathrm{~N} \mathrm{ha}^{-1}$ with a diameter value of $3.10 \mathrm{~cm}$. The minimum diameter of colocasia tuber was recorded in a control that was $2.66 \mathrm{~cm}$. Comparing the increase in diameter over control, it was observed that application of $90 \mathrm{~kg} \mathrm{~N} \mathrm{ha}^{-1}$ increased the colocasia diameter

Table 5. Length of colocasia as influenced by different levels of nitrogen.

\begin{tabular}{ccccc}
\hline Treatments & N levels & $\begin{array}{c}\text { Max. length } \\
(\mathbf{c m})\end{array}$ & $\begin{array}{c}\text { \% increase } \\
(\%)\end{array}$ & $\begin{array}{c}\text { Relative Length } \\
(\%)\end{array}$ \\
\hline T1 & 0 & $4.97 \mathrm{~b}$ & - & 85.02 \\
T2 & 60 & $5.45 \mathrm{a}$ & 9.636 & 93.21 \\
T3 & 90 & $5.72 \mathrm{a}$ & 15.099 & 97.85 \\
T4 & 120 & $5.78 \mathrm{a}$ & 16.387 & 98.95 \\
T5 & 150 & $5.84 \mathrm{a}$ & 17.622 & 100.00 \\
\hline
\end{tabular}

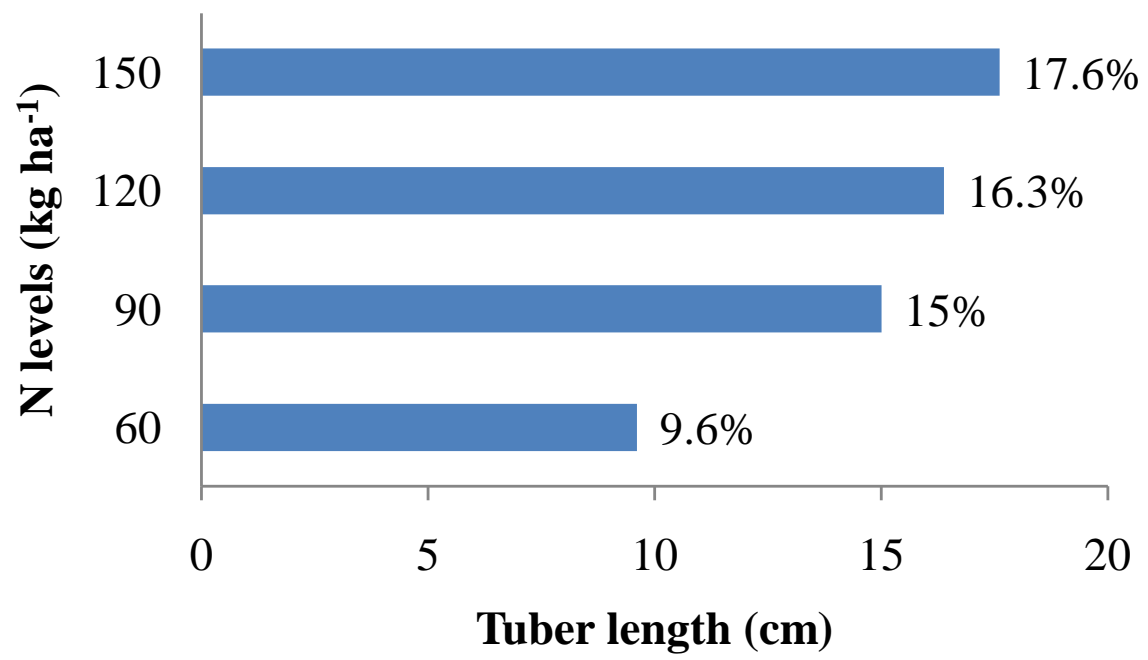

Figure 4. Length of colocasia as influenced by different levels of nitrogen. 
by $18.15 \%$ and it was maximum among all treatments (Table 5, Figure 4). Some researchers have shown that NPK fertilization enhanced growth and corm yield of taro [28] and [29]. It is known that taro consumes substantial amounts of potassium [30]. $\mathrm{N}$ increases the number and length of the internodes and thus results in progressive increase in plant height. Different researchers including [31] [32] [33] made similar observations. However, further application of $\mathrm{N}$ did not further increase this trend, rather it showed the decreasing trend though it was not significant reduction. Both the increase over $60 \mathrm{~kg} \mathrm{~N} \mathrm{ha}^{-1}$ and relative yield (Figure 4) showed the highest value at $90 \mathrm{~kg} \mathrm{~N} \mathrm{ha}^{-1}$ which revealed that it could be the suitable and more economical level of $\mathrm{N}$ for colocasia under the prevailing soil and climatic conditions for the given variety.

\section{Conclusion and Recommendations}

Application of $\mathrm{N}$ produced significantly higher colocasia tuber yield and other yielding components than control but the non-significant difference among the $\mathrm{N}$ levels reveals that the minimum level of $\mathrm{N}$ would be recommended for the given crop cultivar.

\section{References}

[1] Louis, S. (2010) Missouri Botanical Garden “Colocasia Schott subordinate taxa”. Tropicos, Missouri Botanical Garden, St. Louis.

[2] Wirth, F.F., Davis, K.J. and Wilson, S.B. (2004) Florida Nursery Sales and Economic Impacts of 14 Potentially Invasive Landscape Plant Species. Journal of Environmental Horticulture, 22, 12-16.

[3] Rao, V.R.D., Hunter, P.B.E. and Matthews, P.J. (2010) Ethno Botany and Global Diversity of Taro. In: Rao, R.V., Matthews, P.J., Eyzaguirre, P.B. and Hunter, D., Eds., The Global Diversity of Taro: Ethno botany and Conservation, Biodiversity International, Rome, 1-2.

[4] Lee, W. (1999) Taro (Colocasia esculenta) [Electronic Version]. Ethnobotanical Leaflets, 1999, Article 4.

[5] Niba, L.L. (2003) Processing Effects on Susceptibility of Starch to Digestion in Some Dietary Starch Sources. International Journal of Food Science and Nutrition, 54, 97-109. https://doi.org/10.1080/0963748031000042038

[6] Onwueme, I.C. (1978) The Tropical Tuber Crops. John Wiley \& Sons, New York.

[7] Dayrit, R. and Phillip, J. (1987) Comparative Performance of Eight Dryland Taro Varieties on Pohnpei. Federated States of Micronesia.

[8] Tisdale, S.L., Nelson, W.L. and Beaton, J.D. (1990) Soil Fertality and Fertilizers. 4th Edition, Maomillan, New York.

[9] Sanchez, P.A. (1976) Properties and Management of Soils in the Tropics. Wiley, New York.

[10] Buke, T. and Gidago, G. (2016) The Effect of Np Fertlizer Rates on the Yield and yield Components of Taro (Colocasia esculenta (L.) Schott.) in Boloso-Sore Woreda Wolaita Zone, Snnpr, Ethiopia. International Journal of Agriculture Innovations and Research, 5, 329-341.

[11] Steel, R.G.D. and Torrie, J.H. (1984) Principles and Procedures of Statistics. 2nd 
Edition, McGraw Hill Book Co. Ins., Singapore, 172-177.

[12] Gee, G.W. and Bauder, J.W. (1986) Particle-Size Analysis. In: Klute, A., Ed., Methods of Soil Analysis, ASA and SSSA, Madison, 383-411.

[13] Richards, L.A. (1954) Diagnosis and Improvement of Saline and Alkali Soils. Soil Science, 78, 154. https://doi.org/10.1097/00010694-195408000-00012

[14] Nelson, D.W. and Sommers, L.E. (1982) Total Carbon, Organic Carbon and Organic Matter. In: Page, A.L., Miller, R.H. and Keeney, D.R., Eds., Methods of Soil Analysis, Part 2 Chemical and Microbiological Properties, American Society of Agronomy, Inc., Soil Science Society of America, Inc., Madison, 539-579.

[15] Soltanpour, P.N. and Schwab, A.P. (1977) A New Soil Test for Simultaneous Extraction of Macro and Micro Nutrients in Alkaline Soils. Communications in Soil Science and Plant Analysis, 8, 195-207. https://doi.org/10.1080/00103627709366714

[16] Bremner, J.M. and Mulvaney, C.S. (1982) Nitrogen-Total. In: Page, A.L., et al., Eds., Methods of Soil Analysis, ASA and SSSA, Madison, 595-624.

[17] Hartermink, A.E., O’Sullivan, J.N. and Poloma, S. (2000) Integrated Nutrient Management for Sustaining Sweet Potato Yields in the Humid Lowland. Papua New Guinea Food and Nutrition Conference, Lae, 26-30 June 2000, 173-182.

[18] Singh, R.B., Kumar, S.B. and Kumar, S.A. (2011) Effect of Nitrogen and Potassium Levels on Yield and Nutrient Uptake of Colocasia (Colocasia esculenta var. esculenta). International Journal of Agriculture Sciences, 7, 224-226.

[19] Prajapati, M., Singh, P.K., Verma, R.B. and Singh, H.K. (2003) Yield and Quality Response of Colocasia (Colocasia esculenta L.) to FYM, Nitrogen and Potassium Application. Journal of Root Crops, 29, 42-45.

[20] Alam, M.S., Reza, M.H., Islam, M.M., Bhuiyan, M.K.R. and Hossain, M. (2010) Effect of Split Application of NK Fertilizers on the Yield of Panikachu (Colocasia esculenta L.).

[21] Mandal, R.C., Singh, K.D. and Maini, S.B. (1982) Effect of Nitrogen and Potash Fertilization on Tuber Yield and Quality of Colocasia. Vegetable Science, 9, 82-84.

[22] Noor, S., Talukder, M.R., Bhuiyan, M.K.R., Islam, M.M., Haque, M.A. and Akhter, S. (2015) Development of Fertilizer Recommendation for Aquatic Taro (Colocasia esculenta) in Grey Terrace Soil. Pertanika Journal of Tropical Agricultural Science, 38, 83-92.

[23] Verma, R.B., Singh, P.K. and Singh, S.B. (1996) Effect of Nitrogen and Potassium Levels on Growth, Yield and Nutrient Uptake of Colocasia esculenta. Journal of Root Crops, 22, 139-143.

[24] Adam, R.M., McCarl, B.A., Segerson, K., Rosenzweig, C., Bryant, K.J., Dixon, B.L., Corner, R., Evenson, R.E. and Ojima, D. (1998) The Economic Effects of Climate Change on U.S. Agriculture. In: Mendelsohn, R. and Neuman, J., Eds., The Economics of Climate Change, Cambridge University Press, Cambridge, Chap. 2.

[25] Havlin, J.L., Tisdale, S.L., Beaton, J.D. and Nelson, W.L. (2005) Soil Fertility and Fertilizers. Pearson Education, Inc., Upper Saddle River.

[26] Manrique, L.A. (1994) Nitrogen Requirements of Taro. Journal of Plant Nutrition, 17, 1429-1441. https://doi.org/10.1080/01904169409364817

[27] Mehla, C.P., Ram, M. and Singh, J. (1997) Effect of Spacing and Fertilizer Levels on Growth and Yield of Colocasia (Colocasia esculenta L.). Agricultural Science Digest, 17, 205-208.

[28] Udoh, D.J., Ndon, B.A., Asuquo, P.E. and Ndaeyo, N.U. (2005) Crop Production Techniques for the Tropics. Concept Publications Limited, Lagos, 446 p. 
[29] Shiyam, J.O., Obiefuna, J.C., Ofoh, M.C., Oko, B.F.D. and Uko, A.E. (2007) Growth and Corm Yield Responses of Upland Cocoyam (Xanthosoma satitti folium L.) to Sawdust Mulch and NKP 20:10:10 Fertilizer Rates in the Humid Forest Zone in Nigeria. Continental Journal of Agronomy, 1, 5-10.

[30] O’Sullivan, J.N., Asher, C.J. and Blamey, F.P.C. (1996) Diagnostic Criteria for Nutrient Disorders of Taro. In: Craswell, E.T., Asher, C.J. and O’Sullivan, J.N., Eds., Mineral Nutrient Disorders of Root Crops in the South Pacific, Australian Centre for International Agricultural Research, Canberra, 83-90.

[31] Saigusa, M., Kasagaya, Y., Watarable, A. and Shibuya, K. (1999) Ecology of Apple of Pru (Nieandra physalodes L.) Press and Velvet Leaf (Abudtilon avicennae Garth).

[32] Gasim, S.H. (2001) Effect of Nitrogen, Phosphorus and Seed Rate on Growth, Yield and Quality of Forage Maize (Zea mays L.). M.Sc. Thesis, Faculty of Agric., Univ. of Khartoum.

[33] Dauda, S.N., Ajayi, F.A. and Ndor, E. (2008) Growth and Yield of Watermelon ( $\mathrm{Ci}$ trullus lanatus) as Affected by Poultry Manure Application. Journal of Agriculture and Social Sciences, 4, 121-124. 